\title{
Corrigendum
}

\section{Corrigendum to "Pseudolaric Acid B Induces Caspase-Dependent and Caspase-Independent Apoptosis in U87 Glioblastoma Cells"}

\author{
Muhammad Khan $\left(D,{ }^{1}\right.$ Bin Zheng, ${ }^{1}$ Fei Yi, ${ }^{1}$ Azhar Rasul $\left(D,{ }^{1}\right.$ Zhuyi Gu, ${ }^{2}$ Ting Li, ${ }^{1}$ \\ Hongwen Gao $\mathbb{D},{ }^{1}$ Javed Iqbal Qazi, ${ }^{3}$ Hong Yang, ${ }^{2}$ and Tonghui Ma $\mathbb{D}^{1}$ \\ ${ }^{1}$ Central Research Laboratory, Jilin University Bethune Second Hospital, Changchun 130041, China \\ ${ }^{2}$ College of Life Sciences, Liaoning Normal University, Dalian 116029, China \\ ${ }^{3}$ Department of Zoology, University of the Punjab, Quaid-e-Azam Campus, Lahore, Pakistan
}

Correspondence should be addressed to Tonghui Ma; tonghuima@dlmedu.edu.cn

Received 17 August 2020; Accepted 17 August 2020; Published 4 December 2020

Copyright (c) 2020 Muhammad Khan et al. This is an open access article distributed under the Creative Commons Attribution License, which permits unrestricted use, distribution, and reproduction in any medium, provided the original work is properly cited.

In the article titled "Pseudolaric Acid B Induces CaspaseDependent and Caspase-Independent Apoptosis in U87 Glioblastoma Cells" [1], the identity of the cell line has been clarified following the publication of an Expression of Concern [2].

The laboratory director at the Jilin University Bethune Second Hospital obtained the original frozen cell line and sent the cells to a company for STR analysis (see the Supplementary Materials). The board is satisfied that the cell line tested is the glioblastoma cell line U87 or its derivative. Supplementary Materials

Link to archivetempU87细胞STR鉴定实验报告 英文 版.pdf: https://hindawihelp.freshdesk.com/helpdesk/ attachments/48027005360?download=true.

\section{References}

[1] M. Khan, B. Zheng, F. Yi et al., "Pseudolaric acid B induces caspase-dependent and caspase-independent apoptosis in U87 glioblastoma cells," Evidence-Based Complementary and Alternative Medicine, vol. 2012, Article ID 957568, 11 pages, 2012.

[2] Evidence-Based Complementary and Alternative Medicine, "Expression of concern on "Pseudolaric acid B induces caspasedependent and caspase-independent apoptosis in U87 glioblastoma cells"," Evidence-Based Complementary and Alternative Medicine, vol. 2019, Article ID 4959838, 1 page, 2019. 